\title{
自由論題報告
}

\section{東アジアにおける貿易と経済発展 一国際産業連関表による相互依存関係の分析一}

横浜国立大学 長谷部勇一

\section{1.はじめに}

アジアNIES (韓国, 台湾, 香港, シンガポール), Asean4 (インドネシア, マレーシア, フィ リピン，タイ）は，70 年代から 80 年代にかけて，80 年代後半からは中国も含めて，輸出志向型 工業化政策のもと日本やアメリカなどの先進国との貿易を拡大させ，同時に東アジ地域内貿易 と直接投資を通じて域内相互の連関をも拡大してきた。そして，90 年以降は，日本経済のバブル 崩壊にともなう景気の低迷から，アジアNIES 諸国とAsean 諸国内部での直接投資と貿易の拡大 が一層進み，「日本効果」の弱化とは対照的に，NIESを中心とする東アジア諸国内部の「自己循 環入カニスム」が確立し, 従属的な構造から自立的な構造へ転換したという主張がなされている （注 1 ）。他方では，クルーグアン論文による「幻のアジア経済」論（注 2 ）や最近の通貨危機に 端を発した東アジア諸国の経済危機に象幑されるように，この地域の成長基盤は確固としたもの ではなく自立した経済圈であるという見方に对する批判的論調もみられる。確かに 90 年代以後， 東アジア域内諸国の成長率，貿易や直接投資の伸び率に関する限りは, 「NIES効果」が大きくなっ たことは事実であるが，アメリカ，日本，EUという先進国経済からの依存関係から離れて，自己 䛻環型で自立した経済地域として発展したかどうかについては，さらに慎重な分析を要するよう に思われる。

本稿では,アジア経済研究所から公表されているアジア国際産業連関表 (注 3)を用いて, 1985 年から 90 年にかけての東アジア 8 ケ国（香港を除くNIES, Asean4, 中国）とアメリカ, 日本の 計 10 ケ国の貿易構造と経済発展構造を分析することにより，この時期における東アジア諸国のア メリカ・日本経済との依存関係と域内の相互依存関係を明らかにして，「自立」と「自己㥀環」の 程度を明らかにしてみたい。国際産業連関表では通常の国内財の取引以外に，輸出財，輸入財の 部門別・国別・用途別（中間財か最終財か）の産出元と産出先が明示されるので，詳細な国際分 業構造と各国間の相互依存関係の分析が可能になる。期間としては, 90 年から 95 年にかけての桠 造変化を中心対象とすべきであるが，1995 年基準の国際産業連関表の完成はまた数年先の予定で あるため，本稿の分析は，中国を含む東アジア諸国が高度成長した直前の時期に限定される。

\section{2. 東アジア経済発展の基本的指標}

(1) 成長率

アジア国際産業連関表より，各国の経済成長の概要を図 1より見てみよう。1985年と1990年 の表より, 絵生産 (Gross Output) と付加価值の平均成長率を比較したものである。アジア国際 産業連関表では，取引額は当該国の名目価格で評価され，その時点での年平均為替レートでU S ドルに変換された金額で表示されており，日本経済に関する通常の統計における実質価格表示の 円による計算值とは異なっている点に注意を要する。これによれば, 総生産・付加価值のいずれ 
に関しても，韓国，台湾，タイ，日本，シンガポール（高成長グループ）が $15 \%$ か $22 \%$ と非常 に高い成長を記録した。名目価格であるので，各国内の物価上界分を割り引いて考える必要があ るが,なかでも韓国，台湾，タイの高度成長は注目に值する。一方，マレーシア，フィリビン，イ ンドネシア，中国，アメリカ（中成長グループ）は，4\%から9\%であり，10ヶ国平均の $9.8 \%$ を 下回っているものの, 世界の国々の成長から見ると相対的には高い成長であり，東アジア全体が 大きく成長したことがわかる。

\section{（2）貿易額}

図 2 は，各国の輸出と輸入の年平均変化率を示したものである。高成長グループは全般的に輸 出，輸入とも大きくのばしている。中でもタイ、台湾，韓国の輸入增が大きく，高成長による輸 入誘発によるものと考えられよう。中成長グループの中では,フィリビンが大きく輸入を伸ばし たほか，インドネシアの輸出と中国の輸入を除くと，輸出も含めて $10 \%$ か 15\%の伸び率であ り，高成長グループとほぼ同じ傾向であった。

図 3 は輸出額の地域別構成の推移を見たものである。NIESの伸びが一番高く全体で $113.0 \%$ の 增加，地域別では中国，Asean，日本向けが特に伸びている。構成比で見ると，Asean (5.7\%か ら 8.2\%へ)，中国 (5.9\%から 8.7\%へ)，日本 (9.7\%から $12.2 \%$ )，その他世界（38.7\%から $41.9 \%$ へ) と伸ばしたのに対して，アメリカ向けに関しては $39.9 \%$ か $28.9 \%$ と大きく減らし た。2 番目に輸出の伸びが大きかったのが中国であり全体で $106.0 \%$ 増加, 地域別構成比は, Asean (2.9\%から 3.3\%へ), NIES (26.8\%から 41.3\%), 日本 (18.6\%から 16.6\%), アメリカ (11.4\%から 10.6\%)，その他世界（40.3\%から $28.2 \% ）$ と推移し，その他世界，日本，アメリカ から NIESへの輸出シフトが生したことがわかる。ついでアメリカは, $101.3 \%$ の輸出増加を示し ており，特にNIESへの輸出を大きく伸ばした。Asean は，この時期全体で 80.6\%の輸出增加に 留まっているが, 日本, アメリカ向けが停滞し, その構成比も落とした。その代わりに，中国， Asean 向けが拡大している。

輸入に関して見たのが図 4 である。ここでも NIESが $159.4 \%$ と最も増加させた。地域別では， 中国，アメリカからの輸入が大きく拡大し，粠成比もそれそれ $10.4 \%$ か $12.8 \%$ 亿, $14.9 \%$ から $18.3 \%$ とった。日本の占める割合は，25\%程度で変化はなかったが，Asean，その他世界から の渝入は相対的に減少した。Aseanもこの時期 $149.1 \%$ 輸入拡大がみられ, 特に NIES と日本か らの輸入が增大した。一方, アメリカ，その他世界からの輸入が相対的に減少した。日本は，こ の時期輸入は $96.4 \%$ 増加に留まったが, NIES とアメリカからの輸入が拡大した。

以上のように，東アジアは 80 年代後半において NIES ・ Asean 諸国の高い成長と貿易の拡大と いう特徵を持っていることが国際産業連関表からも確認された。なかでも NIES 軸とする貿易 の拡大，中国の比重の相対的增大が注目されるが，絶対額として貿易額をみると，図 $3 ， 4$ から 確認されるように輸出入ともにアメリカと日本が依然として巨大な存在であることを忘れてはな らない。次に，このような特徵を持った䊔造を投入面の依存関係と需要面からの誘発関係という 両面から分析する。 


\section{3. 後方連関分析による投入の依存構造}

(1) 国際産業連関表におけるレオンティエフ逆行列の意味

国際産業連関表においても，形式的には各産業の自国及び外国からの中間財投入額を生産額で 除することにより投入係数（交易係数）を計算し，単位行列とこの投入係数行列との差の逆行列 をとることによってレオンティエフ逆行列を得る。この逆行列を列方向にみれば，ある国のある 産業に 1 単位の需要が発生した場合，自国及び外国の諸産業の財が中間財として直接・間接に必 要とされる額を示す。ここで他国からの必要量は，中間財として直接輸入されるものに加えてそ の軨入財を外国内部で生産するために必要な間接的な財の量も含まれることになる。したがって， 列の各要素は，ある国のある産業の生産を支える自国及び外国の中間財の技術的連関を示すと考 えることができる。この列和を後方連関効果(Backward Linkage)と呼び（注 4)，そのうち外国 ブロックの要素の合計との割合をとれは，その産業の生産に直接間接に必要な外国の中間財に対 する依存度を表すことができる。

\section{（2）全産業の後方連関効果}

本稿では，アジア国際産業連関表の10ケ国 24 部門分類を基本に逆行列を計算したが，その結 果を国ことに要約したのが図 5 である。これはマク口の後方連関効果であり，ある国の平均的産 業に 1 単位の需要があった場合，自国及び外国にどれくらいの波及を及ほすかをあらわす。これ によれば, 後方連関効果は，相対的に小幅に分布しており，Asean，シンガポールでやや低く, 1.7 から 1.8 の值をとり，中国，シンガボールを除くNIES及び日本，アメリカで 2.0 前後とやや高い 值になっている。 85 年から.90 年にかけての推移では, 中国が最も伸ばし 2.2 に增加した。その他 では, マレーシア,フィリピン, インドネシアが数\%上昇し, 日本, アメリカ, タイ, シンガポー ルで数\%の低下がみられた。外国依存度では, シンガポールが最も高く(85 年 $22.5 \%, 90$ 年 25.5 \%)，続いてマレーシア $(19.2 \%, 17.9 \%)$, タイ $(9.6 \%, 13.3 \%)$, フィリビン $(9.3 \%, 14.1 \%)$ である。台湾 $(9.7 \%, 11.0 \%)$ と韓国 $(11.3 \%, 9.8 \%)$ は，10\%前後であり，85 年から 90 年に かけての後方連関効果の推移では逆の動きを示した。日本 $(3.8 \%, 3.2 \%)$ とアメリカ $(1.4 \%$, $1.5 \%$ ）は，投入面での外国依存の低さを示している。中国（3.1\%，3.1\%) は，日本と同程度の 低さであり，90 年段階では経済開放が進展したものの中間財の投入面では社会主義計画経済時代 の自給自足型発展の影響が強く残っていると考えられる。

\section{（3）機械産業の後方連関効果}

1985 年と 90 年に関して産業全体の後方連関効果の外国依存に関してみると、シンガボールと マレーシアを除けば大きな隔たりは見られない。しかし，個々の産業ことにこの外国依存度をみ てみると，近代的産業の投入の中心をなす機械産業，金属産業，化学産業などの後方連関効果に しめる外国の割合は，NIES，Aseanともにかなり高くなるのに対して，日本，アメリカの場合か なり低くなる。図6は，機械産業を例にとって見たものであるが，日本とアメリカか $3 \%$ から $4 \%$ 台であるのに対して，シンガポール（85 年 $38 \% ， 90$ 年 $43 \%) ，$ マレーシア $(37 \%, 29 \%) ，$ イン ドネシア $(33 \%, 15 \%)$ ，フィリピン $(27 \%, 34 \%)$, タイ $(20 \%, 38 \%)$, 台湾 $(20 \%, 23 \%)$ ， 韓国（22\%，20\%）となり，4\%から 6\%の中国を除くと全体的に外国依存度が高く，图では表わ れていないが日本への依存がほとんどの国でそのうちの半分を占めている。 
このように, 後方連関効果の分析から各国の投入面の構造を見てふると, 85年から 90 年にかけ て韓国，インドネシア，マレーシアでは産業全体では，外国依存度をやや低めているものの，日 本やアメリカの水準までには到達しておらず，機械産業，金属産業などではさらにその差が開い ていることが明らかになった。

\section{4. 生産誘発分析と需要の依存構造}

（1）生産誘発分析の方法

レオンティエフ逆行列に各国の最終需要ベクトルを右から掛けることにより，各国の最終需要 により誘発された生産額ベクトルが得られる。その生産額ベクトルの各要素を各国の最終需要絵 額で除したものが生産誘発係数であり，ある国で最終需要 1 単位が生じた場合，自国及び外国の 各産業に直接，間接に誘発した生産額を示す。また，誘発された生産額ベクトルの各国ことの和 が総生産額になるので, 各国最終需要によって誘発された生産額べクトルの要素を総生産額で除 したものを生産誘発依存度といい, 各国の各産業が自国及び他国の最終需要にどの程度誘発され たかを明らかにすることができる。

\section{(2) 生産誘発係数}

図 7 は，各産業ことの誘発額を国ことに集計し，各国で 1 単位の最終需要が生した場合，自国 及び他国にどれくらいの生産誘発を引き起こすかを表したものである。総計の誘発係数でみると， 1985 年では，香港，その他世界，中国の最終需要が 2.0 から 2.3 という高い水準にあり，その他 の国は 1.6 から 1.9 の範囲にあり，そう大きな開きは見られない。90 年では, 中国が 2.3 と大き 伸ばしたこととタイが1.5へと大きく減少させた点が注目されるが，それ以外では大きく変化して はいない。しかし，外国に対する生産誘発係数という点から見ると，日本とアメリカは非常に低 く，国内に波及する割合が $97 \%$ 前後であり，両国の最終需要の大部分は自国内の生産を誘発する という構造になっていることがわかる。逆に，それ以外の国では中国（国内誘発割合 85 年 $93 \%$ ， 90 年 96\%) を除けば，全体的に自国産業への誘発度は相対的に低く，シンガポール $(64 \%, 53$ \%), マレーシア $(78 \%, 63 \%)$, タイ $(87 \%, 79 \%)$, 台湾 $(86 \%, 84 \%)$, フィリビン $(93 \%$, $85 \%)$, 韓国 $(87 \%, 88 \%)$ ，インドネシア $(92 \% ， 89 \%)$ となっており，最終財や中間財の輸 入誘発が日本，アメリカと比べると相対的に大きいことがわかる。

（3）生産誘発依存度

生産誘発係数で見る限りは，各国間で大きな隔たりは見られないが，現実の生産誘発額は，誘 発係数に各国の最終需要を掛けて得られるので, 最終需要の絶対額も大きな規定要因となる。そ こで, 各国の生産が自国及び他国の最終需要によっでどの程度現実に誘発されたのかを表す最終 需要依存度をみたのが図8である。ここでも, 各国の最終需要により誘発された各産業ことの生 産額を国ことに集計してある。ここでも日本 (85 年 $84 \% ， 90$ 年 $88 \%$ ) とアメリカ $(93 \%, 90 \%)$ における内需の割合が高いことが注目される。ついで中国 (90\%，82\%)，インドネシア $(81 \%$ ， $79 \%)$ ，フィリピン $(80 \%, 79 \%)$ ，韓国 $(71 \%, 75 \%)$ ，タイ $(76 \%, 74 \%)$ ：台海 $(52 \%, 60$ \%), マレーシア $(63 \%, 51 \%)$, シンガボール $(40 \%, 33 \%)$ と外需依存型の傾向が強くなうて いる。また; 85 年から 90 年にかけて外需に占める国別の割合では, すへての国で台湾, 韓国, 香 港; 日本の最終需要への依存度が高まっており, 逆にアメリカへの依存度が低くなる傾向にある。 中でも日本の割合はほとんど国で上昇しており，日本の最終需要 (=国内総支出) の絶対的增 
加が大きな要因となって, 東アジアの成長の牽引力になったという「日本効果」.存在を確認で きる。

\section{5. 小活}

(1) 後方連関効果という視点から各国の投入錸造を比較してみると，日本やアメリカが自国内の 産業に依存する割合が非常に高いのに対して，Asean，NIES諸国は，一部で自国内産業の割 合を高めているものの，全体の棈造としては他国特に日本やアメリカに依存する割合が高く， 機械，金属，化学産業などではその傾向が一層強まることが確認された。

(2) 生産誘発分析という視点から各国の自国及び他国の最終需要への依存度について比較してみ ると, 日本, アメリカの内需依存度がかなり高いのに比べて Asean, NIES諸国は，一部に内 需依存度を高めているもの, 全体の構造としては日本，アメリカの水準とはかなりの隔たり があること，外需における日本の比重の大きさが確認された。

（3）以上より，日本とアメリカの経済構造は，投入面からみると中間財に関して自国依存型であ り, 最終需要面からみると内需依存型であり,これらを総合して「日米型自立的構造」とみ るならば(注 5 )，NIES諸国特に韓国，台湾はその方向へ一歩発展したことは確かであるが， 90 年段階ではまだ日本やアメリカのレベルとは大きな隔たりがある。また，東アジア諸国が 「成長の毫引力」としての役割を担うかどうかという点では，経済の絶対規模も重要な要因で あり，単純に成長率，貿易額，誘発係数の大きさからのみ評価することはできない。

（4）絶対額という点からいうと, 中国の東アジアにおける相対的比重の大きさということも確認 されるべきで，国内総生産（GDP）で見ると 1990 年の日本を 100 とすれば韓国（8.7）や台 湾 (5.4) をしのぐ 12.0 という大きさであり，また生産誘発依存度でも NIES 全体と変わらぬ 大きさを有している。

（5）90 年以降，NIES，Asean，中国が高度成長し，また貿易額を拡大しているが，このことか ら東アジアの「自立」や「自己偱環メカニスム」の成立まで直ちに結論つけることは早急で あり，各国各産業の投入面と需要面の両面からの相互依存関係の分析が必要である。また， 「自立的構造」の評価には，多国籍企業による外国直接投資の動向や企業内国際分業の拡大と いう視点からの分析も重要であり，政治経済学的視点からの検討（注 6) が必要であると思 われる。

* 紙幅の関係から, 国際産業連関モデルの説明, 各係数の計算式, 計算結果の表を省略したが, 近刊の『エコノミア』(1999 年 1 月発行予定)で, 24 部門レベルでの詳細な結果, DPG (Deviation from Proportional Growth) 分析を応用した国際産業連関表の要因分析，スカイ ライン分析，東アジアにおける CO2 環境収支の試みなどを発表する予定である。

注 1. 代表的論者として，渡辺氏は，「東アジアは，輸出財の需要先と投資資金の供給先を域内に 求める新しい運動を開始したのである。モノとカネを域内で自己循環させることにより， 域外先進国への依存を低めながらなお高成長を追い求める条件を，東アジアはついに手に 入れたというべきである。と主張している(渡辺利夫『開発経済学 第 2 版』 254 ページ)。 注 2.MITのポール・クルーグマン教授は, 東アジア諸国の全要素生産性（TFP）の低さを理由 
に高度成長は続かないと主張した。

注 3 . 過去アジア経済研究所では，1958，60，63 年を対象にしたチェネリー・モーゼス型のア ジ国際産業連関表を作成したが，その後より詳細な国際間取引を含むアイサード型の国 際産業連関表を 75,85 年を対象にして作成, 公表している。なお, 香港は, そもそも信 頼ある機関から産業連関表が公表されていないため, 1975 年以降アジア国際産業連関表で は内生部門ではなく，外生部門として位置つけている。

注 4. 各列和の列和平均との相対比を影響力係数という。また,レオンティエフ逆行列の行和を 前方連関効果(Forward Linkage)といい, 各行和の行和平均との相対比を感応度係数とい う。

注 5 . 自立型経済構造に関しては,イギリス,ドイッ,フランスなど貿易依存度が高く従って投 入面でも需要でも外国依存の高い先進国もあり，ハイテク産業の動向などより詳細な産業 別の分析に基づいた「自立型経済構造」の概念規定が必要である。

注 6.たとえば, 中村雅秀『アジアの新工業化と日本』, 佐藤元彦・平川均『第四世代工業化の政 治経済学』など参考。

\section{参考文献}

(1)佐藤元彦・平川均『第四世代工業化の政治経済学』新評論，1998年。

(2)中村雅秀『アジアの新工業化と日本』青木書店, 1997 年。

(3)文大宇・武田晋一「国際産業連関表分析によるアジア太平洋地域の経済関係」『イノベーショ ン\&I Oテクニーク』Vo15，No3，1994 年。

(4)渡辺利夫『開発経済学第 2 版』日本評論社, 1996 年。

(5) Institute of Developing Economies, Asian International Input-Output Table 1985, IDE Statistical Data Series No65, Tokyo,1992:

(6) Institute of Developing Economies, Asian International Input-Output Table 1990, IDE Statistical Data Series No81, Tokyo,1998.

(7)P. Krugman "The Myth of the Asia's Miracle", Foreign Affairs, 1994 Nov/Dec. 
图1，1985-90平均成長事

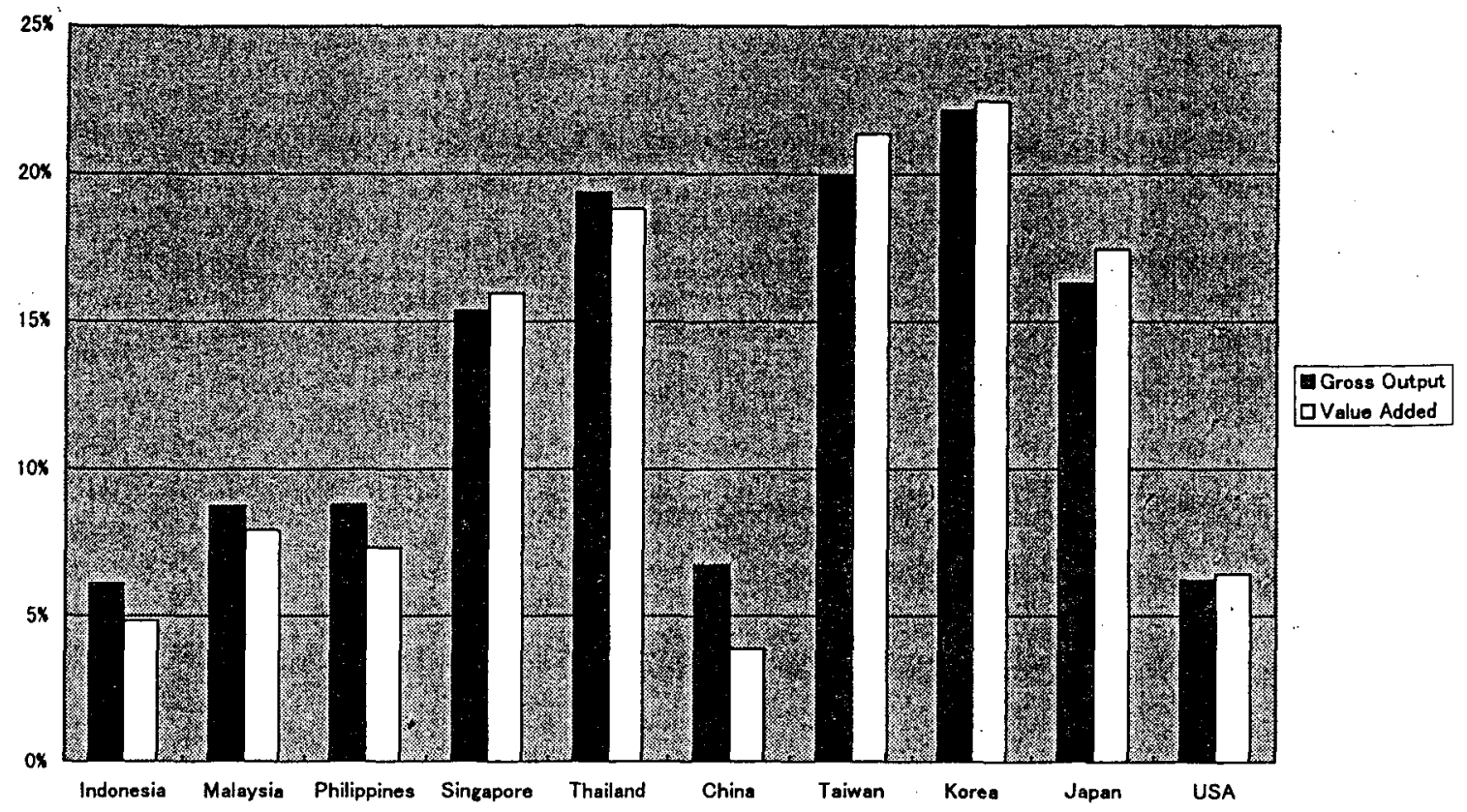

图2。出入平均表化事

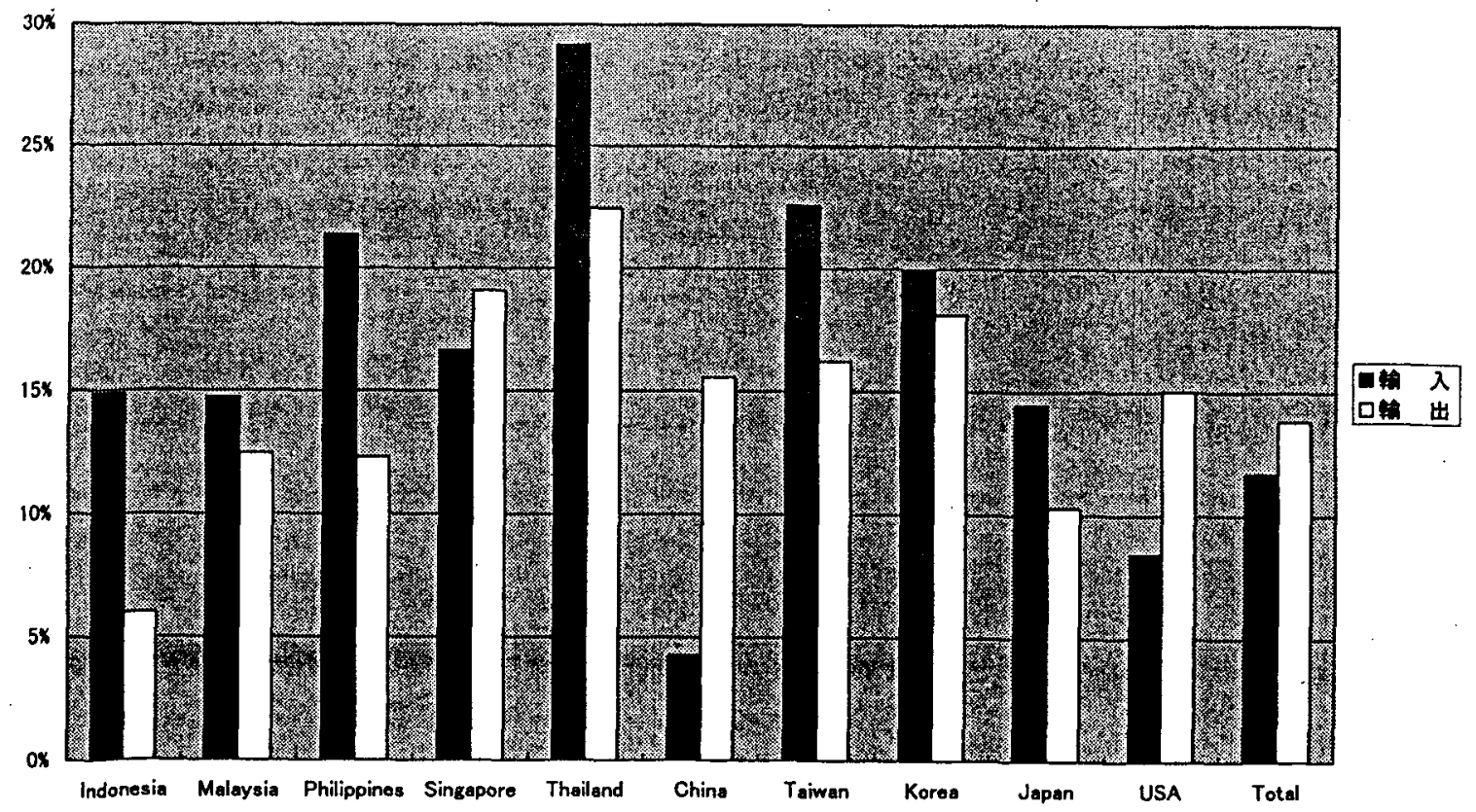


图3. 地域別輸出植 $(1985-90)$

(1,000US\$)

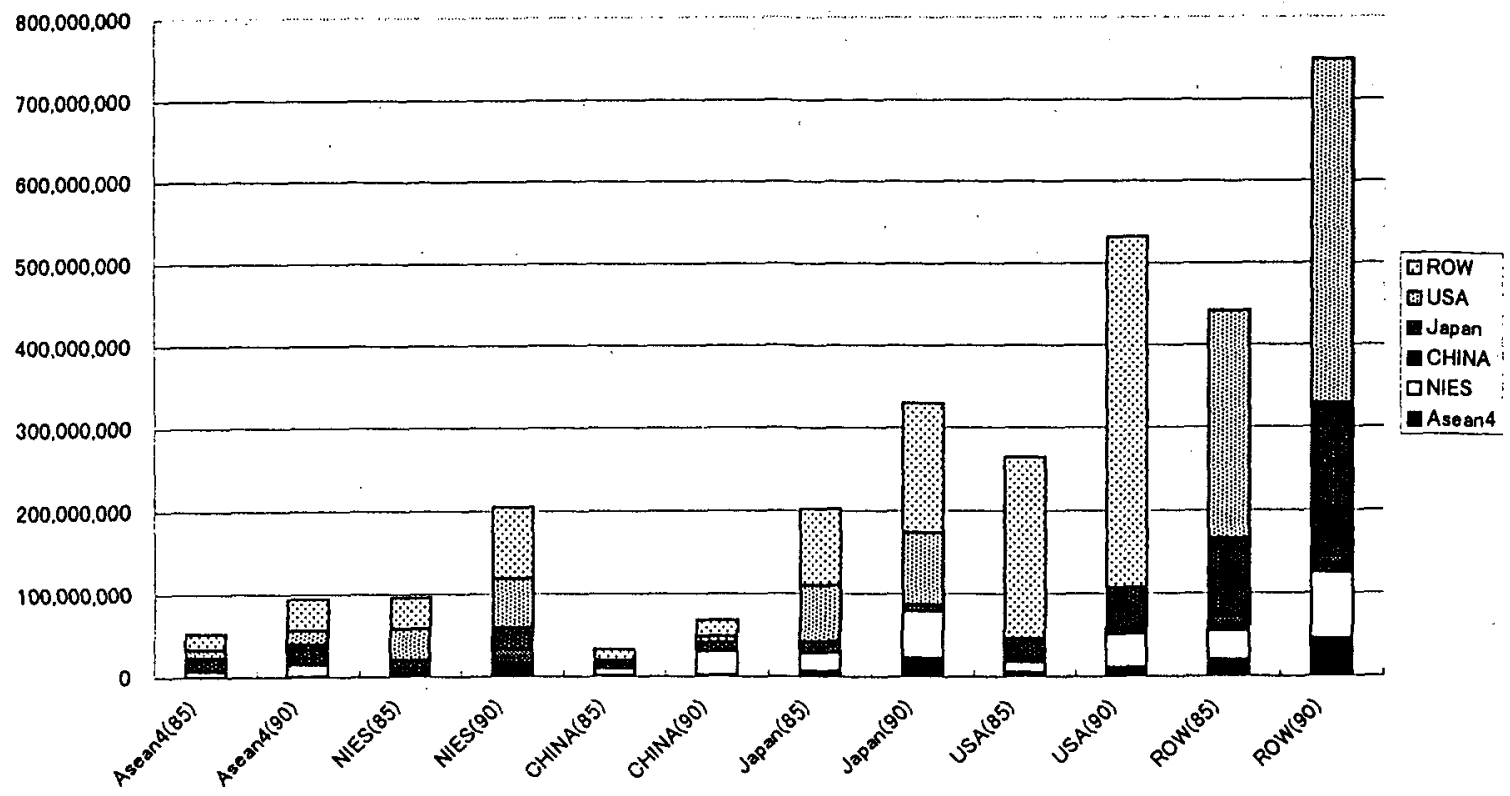

图4. 地城別输入䫓 $(1985-90)$

(1,000us\$)

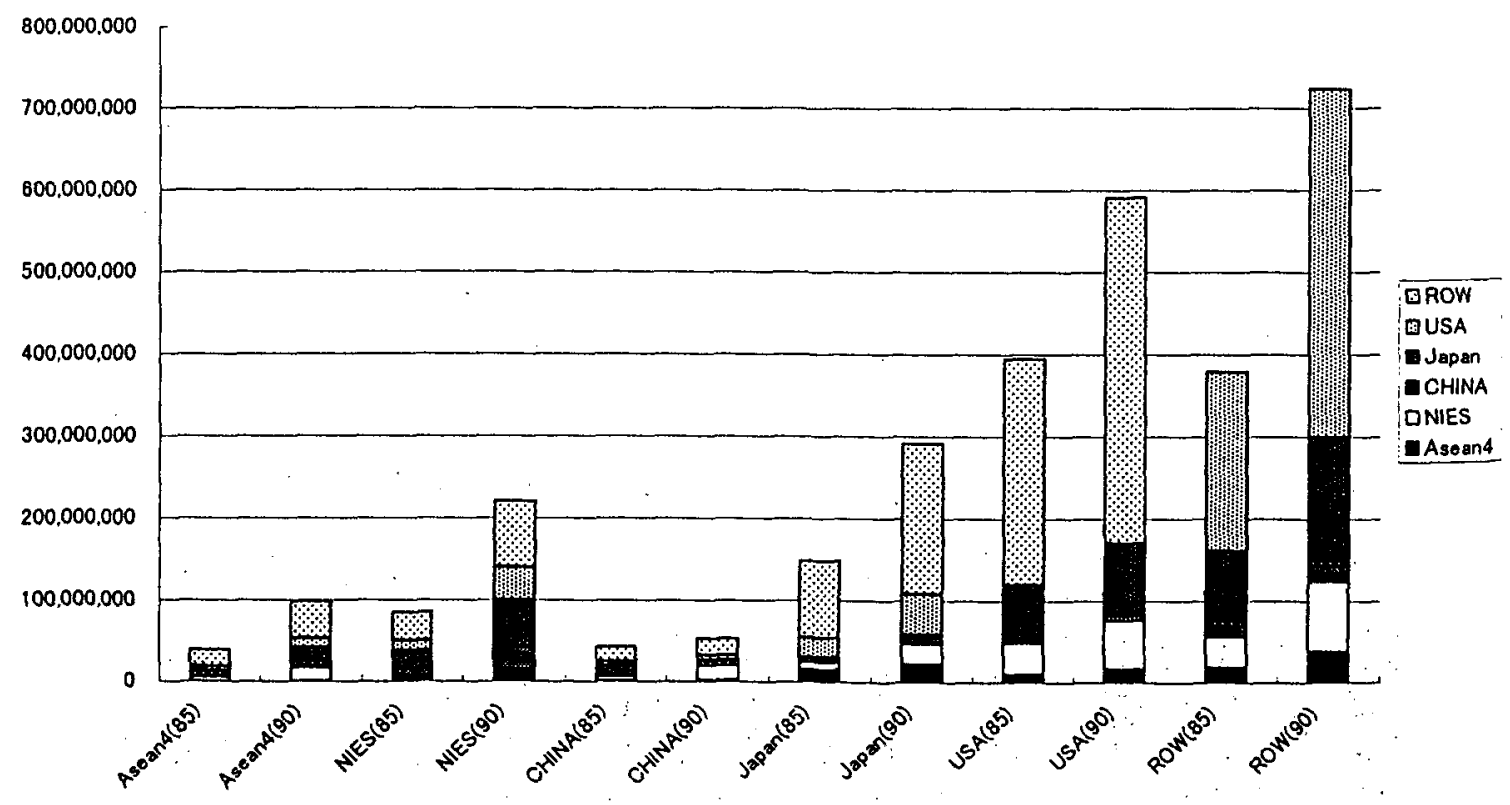


图5. 绻方逜関勃果の推移(1985-90)

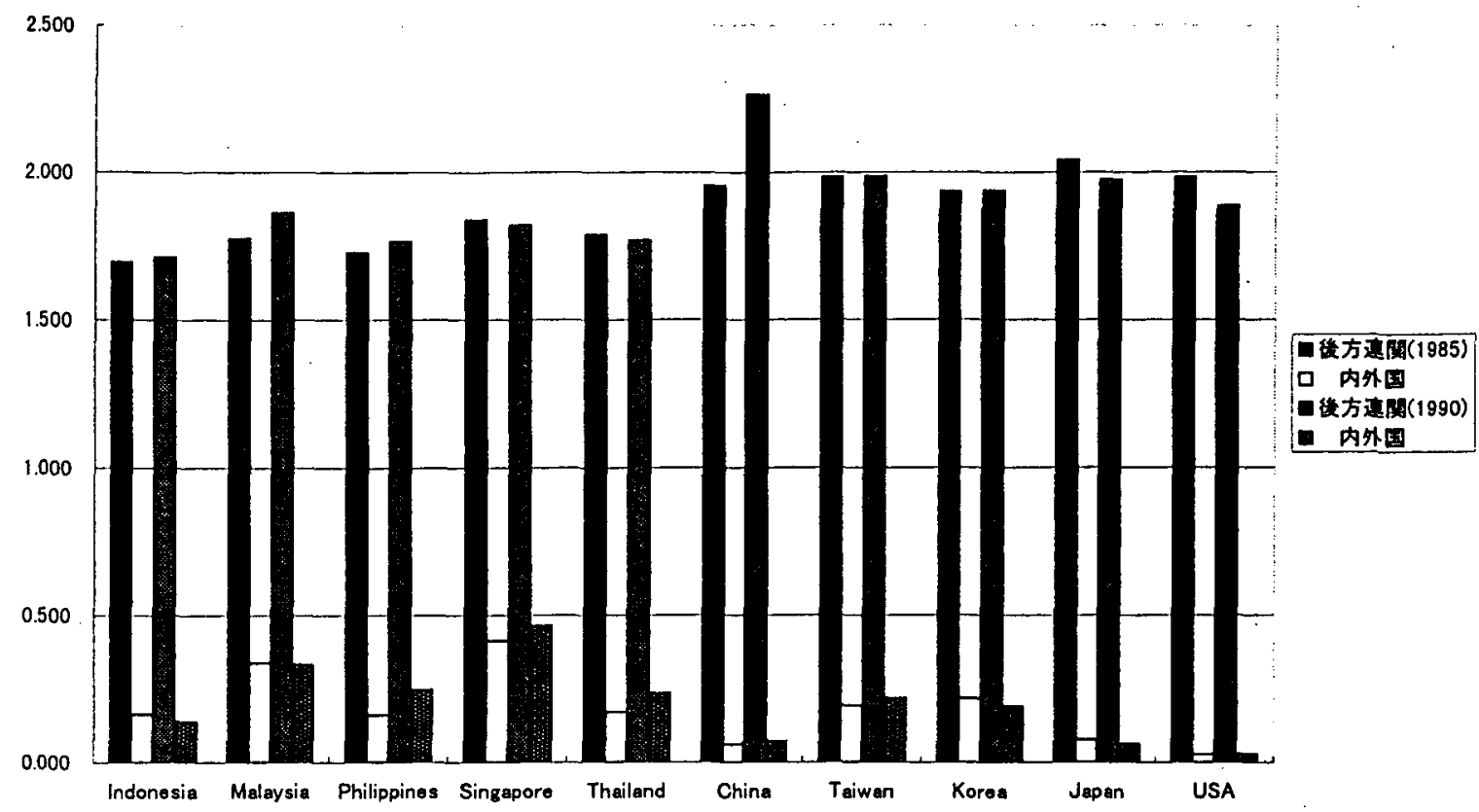

图6. 機械産乘における绻方連閏効果の推移

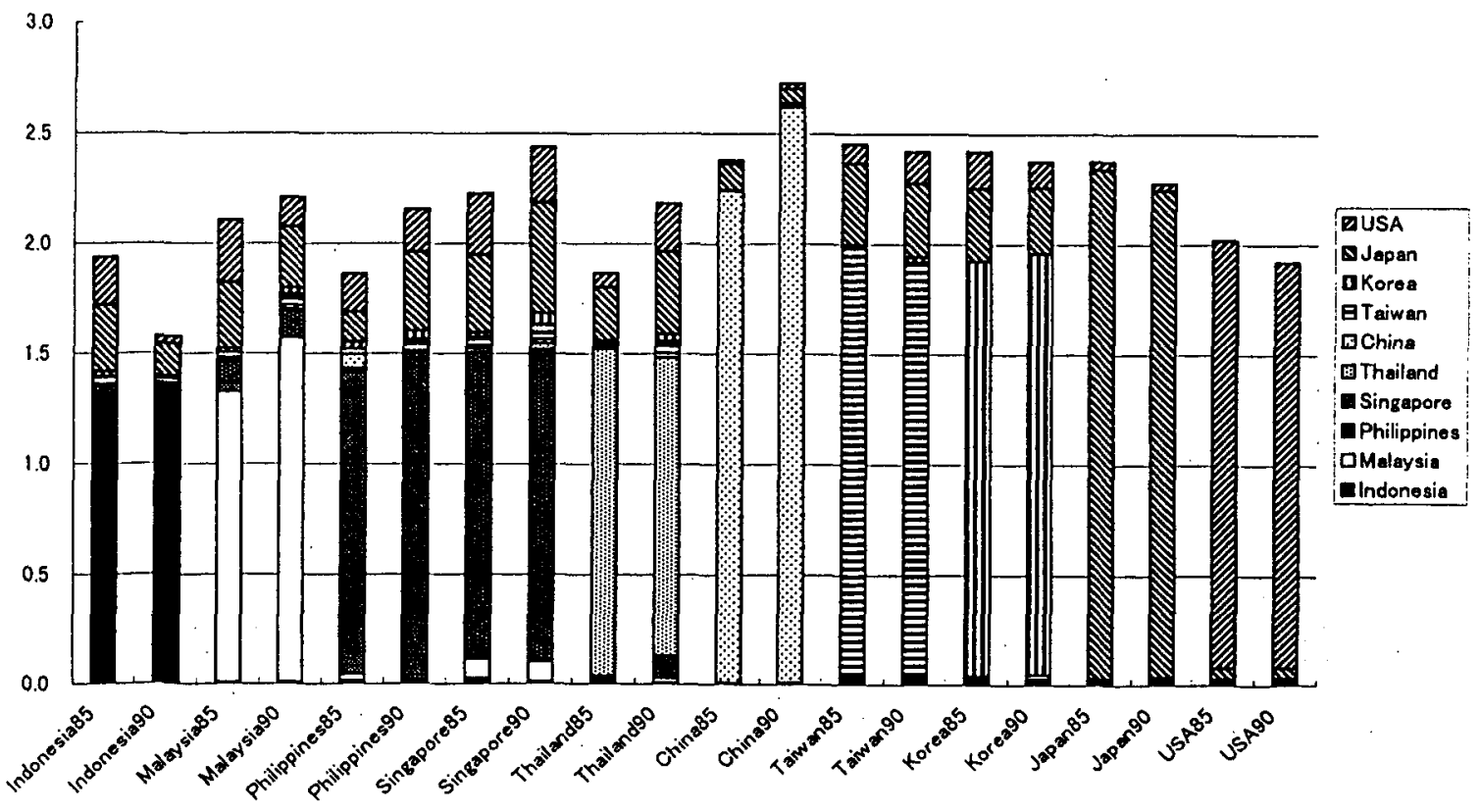


図7. 生産誘発保数と国別梙成の推移

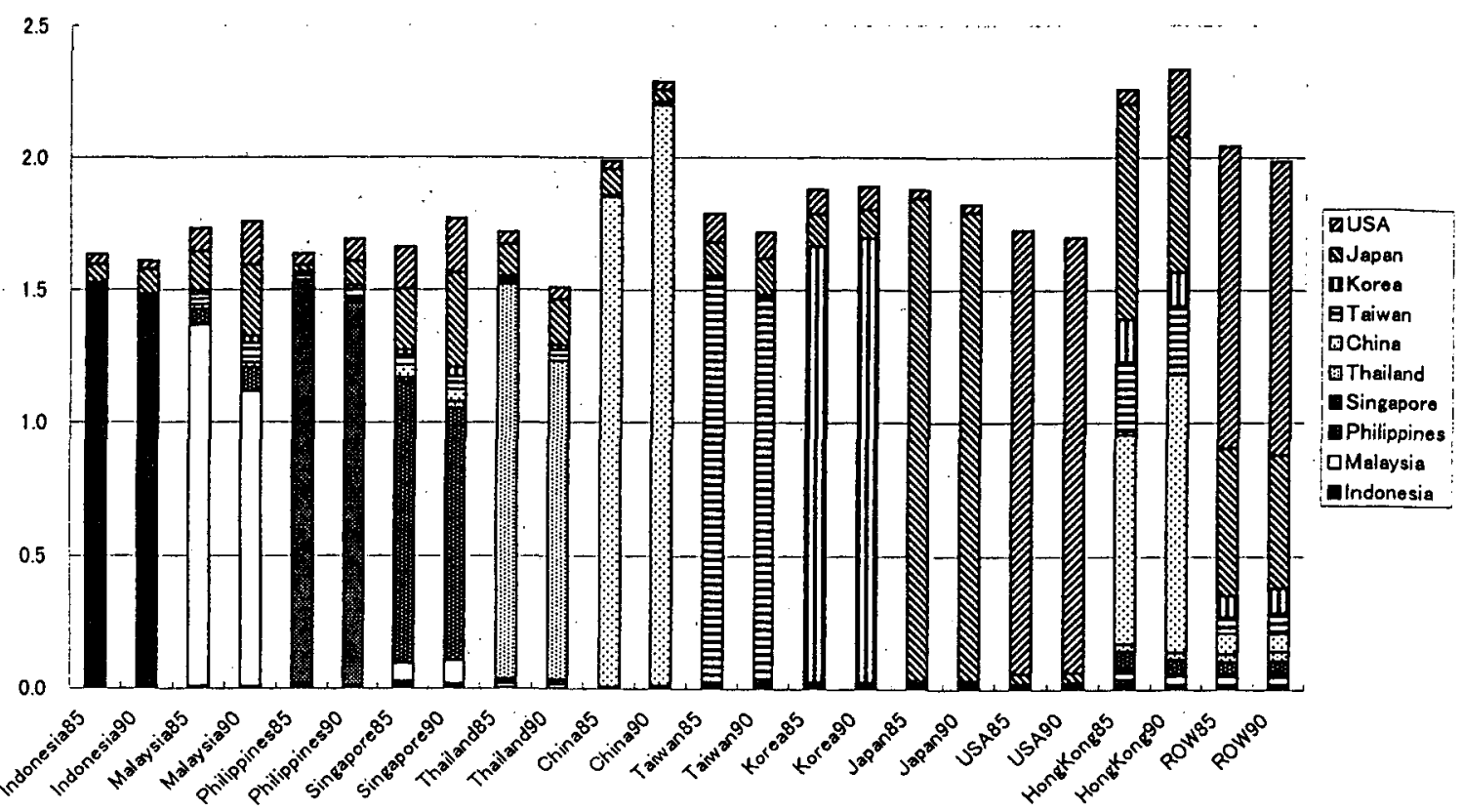

图8. 国別生库誘発依存度の推移

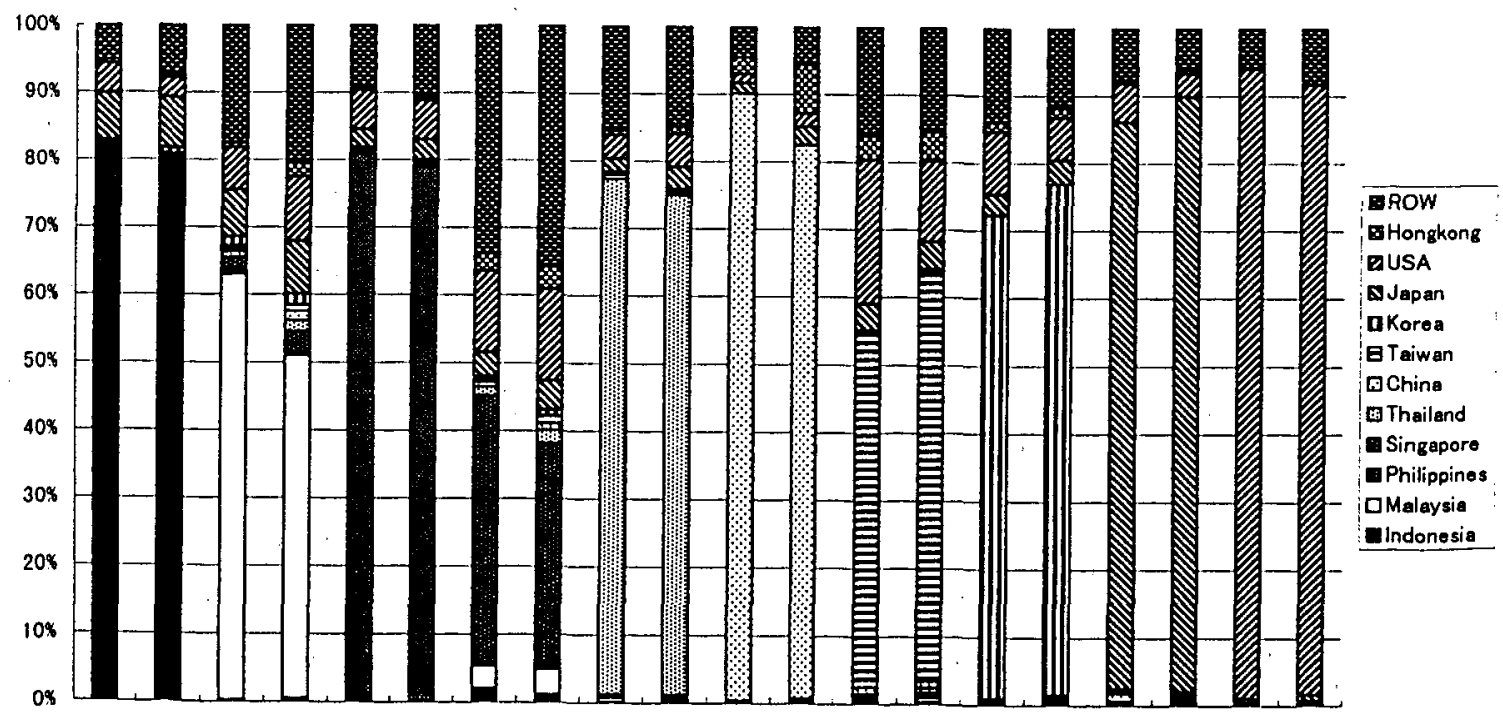

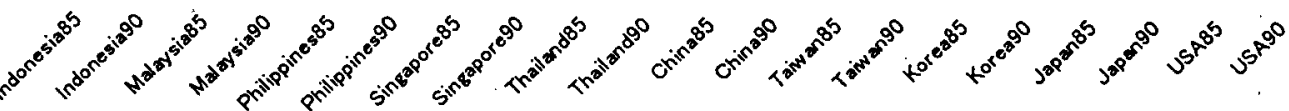

